\title{
Studying the biochemical transformations in sherry wines subjected to biological aging
}

\author{
Sofia Cherviak ${ }^{1, *}$, Victoria Gerzhikova ${ }^{1}$, Nadezhda Anikina ${ }^{1}$, Nonna Gnilomedova ${ }^{1}$, and \\ Antonina Vesyutova ${ }^{1}$ \\ ${ }^{1}$ All-Russian National Research Institute of Viniculture and Winemaking "Magarach" of RAS, \\ 298600 Yalta, Russian Federation
}

\begin{abstract}
The fundamental role in the process of biological aging is given to yeast which enrich the wine with substances that contribute to the formation of the characteristic organoleptic properties of sherry. We studied 55 samples of wine in the dynamics of biological aging. The purpose of this research was to study the transformation of wine components during biological aging and to determine their technological value. Generalization of experimental data showed that biological aging determines changes in the composition of wines and physical-chemical characteristics: reduction of the volume fraction of ethanol, the mass concentration of the components of the acid complex (malic, lactic and acetic acids), amine nitrogen and glycerin as sources of energy and carbon nutrition for yeast. Decrease in the content of phenolic substances, the value of the redox-potential of wine and optical density $\mathrm{D}_{420}$ confirms the protective function of the sherry film that prevents non-enzymatic oxidation of wine components. The biological aging is also characterized by an increase in the mass concentration of aroma-forming substances: acetaldehyde, diacetyl, acetoin, dioxanes, dioxolans, lactones. Based on the data obtained, the role of the main components of wines in the process of biological aging and the ranges of their variation were determined.
\end{abstract}

\section{Introduction}

The fundamental role in the process of biological aging is given to yeast which, as a result of its development, as well as autolysis, enrich the wine with substances that contribute to the formation of the characteristic organoleptic properties of sherry [1-6]. The physiological state and metabolism of the yeast cell is influenced by the content of nutrient components, process inhibitors (sulfurous acid, lactic and acetic acid bacteria), as well as technological factors $[1,5,7]$. The oxidative metabolism of yeast results in the produced substances that provide the typical aroma and flavor properties of sherry wines [2, 8-15].

Presently, control over the biological aging is carried out by the accumulation of the mass concentration of acetaldehyde, as well as by the transformation of the organoleptic characteristics of the product. Studying the qualitative and quantitative changes in the

\footnotetext{
*Corresponding author: Sofi4@list.ru
} 
component composition under the action of flor yeast to substantiate additional criteria for assessing the quality of Sherry-type white wine called "Fino" is relevant.

The purpose of this research was to study the transformation of wine components in the process of biological aging, as well as to determine their technological value.

\section{Study objects and methods}

The objects of our research were base wines from grapes of the 'Aligote' and 'Rkatsiteli' varieties, enriched with ethyl alcohol to provide the conditions of $16.0 \%$ vol. Biological aging of the samples was carried out by a film method using the sherry yeast race Jerez 20 $\mathrm{C} / 96$. The formation of a continuous sherry film on the surface of the wine was observed after 9-13 days. We analyzed 55 samples of wines in dynamics (before laying for biological aging, 1, 3, 5 months after sowing sherry film). Microbiological control and monitoring of the state of the yeast was performed every 2 weeks.

In wines, optical and potentiometric characteristics were determined [16, 17]. The organic acid profile and glycerol content were determined by the HPLC method on a Shimadzu LC20 Prominance chromatograph (Japan). The component composition of the aromatic complex of wines was carried out using high performance liquid chromatography by means of the Agilent Technologies system.

\section{Results and Discussion}

Generalization of the literature data and research results shows that the metabolism of sherry yeast which can adapt to conditions of a limited amount of nutrients is the basis of complex biochemical transformations of the components of wine, as well as the formation of specific organoleptic characteristics of sherry wine. The main sources of carbon and energy nutrition of sherry yeast include ethyl alcohol, the consumption of which in the process of biological aging is $1-3 \%$ vol., and glycerin, the content of which is reduced to trace levels. Yeast also assimilates organic (malic, lactic, acetic) and amino acids as substrates. Analysis of the literature data $[2,5,8]$ and the results of studies of the dynamics of biological aging made it possible to establish the role of the main components of wine under the action of flor yeast, as well as to determine the ranges of their change (Table 1).

Table 1. The role of wine components under the action of flor yeast

\begin{tabular}{|c|c|c|c|}
\hline Component & Participation in the metabolism of sherry yeast & $\begin{array}{c}\text { Change } \\
*\end{array}$ & $\begin{array}{c}\text { Range of } \\
\text { changes** }\end{array}$ \\
\hline $\begin{array}{c}\text { Ethanol } \\
(\% \mathrm{v} / \mathrm{v})\end{array}$ & $\begin{array}{c}\text { Substrate of oxidation-reduction processes, source of carbon } \\
\text { nutrition, source of energy for metabolite synthesis }\end{array}$ & $\downarrow$ & $16,5 \rightarrow 13,0$ \\
\hline $\begin{array}{c}\text { Acetaldehyde } \\
(\mathrm{mg} / \mathrm{L})\end{array}$ & $\begin{array}{c}\text { The product of ethanol oxidation; is involved in the constructive } \\
\text { exchange of sherry yeast in the form of Acetyl-CoA and obtainment } \\
\text { of energy through the Krebs cycle and glyoxylate cycle }\end{array}$ & $\uparrow$ & $50 \rightarrow 1000$ \\
\hline $\begin{array}{c}\text { Glycerol } \\
(\mathrm{g} / \mathrm{L})\end{array}$ & $\begin{array}{c}\text { Is involved in the process of osmoregulation, gluconeogenesis, and } \\
\text { synthesis of triacylglycerols }\end{array}$ & $\downarrow$ & $\begin{array}{c}7,0 \rightarrow \text { trace } \\
\text { amounts }\end{array}$ \\
\hline $\begin{array}{c}\text { Acetic acid } \\
(\mathrm{g} / \mathrm{L})\end{array}$ & $\begin{array}{c}\text { Is involved in the Krebs cycle in the form of Acetyl-CoA for } \\
\text { obtainment of energy and synthesis of intermediate metabolites, as } \\
\text { well as in the glyoxylic cycle and gluconeogenesis }\end{array}$ & $\downarrow$ & $0,4 \rightarrow 0,1$ \\
\hline $\begin{array}{c}\text { Lactic acid } \\
(\mathrm{g} / \mathrm{L})\end{array}$ & $\begin{array}{c}\text { Is involved in the processes of gluconeogenesis and the Krebs cycle } \\
\text { through Acetyl-CoA }\end{array}$ & $\downarrow$ & $1,3 \rightarrow 0,9$ \\
\hline $\begin{array}{c}\text { Amino acids } \\
(\mathrm{g} / \mathrm{L})\end{array}$ & Is involved in the formation of amino acids and protein biosynthesis & $\downarrow$ & $150 \rightarrow 90$ \\
\hline
\end{tabular}

$* \downarrow$ - reduction, $\uparrow$ - increase

** The table shows the average values for the studied selection of samples 
As a result of oxidative metabolism of sherry yeast, the medium is enriched with new components that determine the specific organoleptic properties of sherry (Table 2). Due to the oxidation of ethanol, acetaldehyde is formed under the action of the alcohol dehydrogenase enzyme the amount of which can reach $1000 \mathrm{mg} / \mathrm{l}$ and higher. As a result of its high reactivity, acetaldehyde reacts with the components of wine forming specific products for sherry-type wine: 1,1-diethoxyethane with ethanol, dioxanes and dioxolanes with glycerin, and sotolon with $\alpha$-ketobutyric acid. In addition, acetoin and diacetyl are formed enzymatically $[1,4,8,14]$.

Table 2. Products of metabolism of yeast in the process of biological aging

\begin{tabular}{|c|c|c|}
\hline $\begin{array}{l}\text { Component or class } \\
\text { of materials }\end{array}$ & Ways of formation & Technological value \\
\hline Acetaldehyde & Alcohol oxidation & $\begin{array}{c}\text { Affects the organoleptic properties of sherry } \\
\text { wine; characterizes the course of biological } \\
\text { aging }\end{array}$ \\
\hline $\begin{array}{l}\text { Ketones (diacetyl, } \\
\text { acetoin) }\end{array}$ & Binding of excess acetaldehyde & $\begin{array}{l}\text { Affect organoleptic characteristics; give milk } \\
\text { and cheese tones }\end{array}$ \\
\hline Aliphatic aldehydes & Oxidation of higher alcohols & $\begin{array}{l}\text { Affect organoleptic characteristics, give bread } \\
\text { tones }\end{array}$ \\
\hline Aliphatic acetals & $\begin{array}{l}\text { Formed from acetaldehyde and } \\
\text { ethanol (or higher alcohols) }\end{array}$ & $\begin{array}{c}\text { Contribute to the softening and harmonization } \\
\text { of the pungent aroma of aldehydes }\end{array}$ \\
\hline $\begin{array}{l}\text { Cyclic acetals } \\
\text { (dioxanes, } \\
\text { dioxolanes) } \\
\end{array}$ & $\begin{array}{l}\text { Formed from acetaldehyde and } \\
\text { glycerol }\end{array}$ & $\begin{array}{l}\text { Affect the organoleptic characteristics of } \\
\text { sherry wine }\end{array}$ \\
\hline Lactones & $\begin{array}{l}\text { Formed from keto acids on the } \\
\text { way of synthesis of amino acids }\end{array}$ & $\begin{array}{l}\text { Responsible for specific sherry tones in a } \\
\text { bouquet of sherry wine }\end{array}$ \\
\hline Volatile ethers & $\begin{array}{l}\text { Formed from ethanol and higher } \\
\text { alcohols and volatile acids }\end{array}$ & Affect the organoleptic characteristics of wine \\
\hline Non-volatile ethers & $\begin{array}{l}\text { Formed from ethanol, higher } \\
\text { alcohols and organic acids }\end{array}$ & They are a sign of aging \\
\hline Aromatic aldehydes & $\begin{array}{l}\text { They are a product of ethanolysis } \\
\text { of lignin from oak wood }\end{array}$ & They are a sign of aging \\
\hline Furan derivatives & $\begin{array}{l}\text { Formed from sugars and amino } \\
\text { acids }\end{array}$ & Give a nutty tone to the bouquet \\
\hline $\begin{array}{l}\text { Alcohols } \\
\text { C6-C12 }\end{array}$ & $\begin{array}{l}\text { Formed from keto acids in the } \\
\text { synthesis of amino acids }\end{array}$ & They are background flavor components \\
\hline Higher alcohols & $\begin{array}{l}\text { Formed from keto acids in the } \\
\text { synthesis of amino acids }\end{array}$ & They are background flavor components \\
\hline
\end{tabular}

In addition to biochemical transformations, the optical and potentiometric characteristics of wine undergo changes under the action of flor yeast (Table 3): the optical density of $\mathrm{D}_{420}$ and the oxidation reduction potential decrease which confirms the protective function of the sherry film which, by consuming dissolved oxygen, prevents non-enzymatic oxidation of wine components $[5,11]$. As a result of coagulation with yeast cells and subsequent sedimentation, the content of phenolic complex components decreases.

Table 3. Changes in the physical and chemical properties of wine in the process of biological aging

\begin{tabular}{|c|c|c|}
\hline Indicator & Technological value & Range of changes* \\
\hline Optical density $\mathrm{D}_{420}$ & \multirow{3}{*}{$\begin{array}{l}\text { prevents non-enzymatic } \\
\text { oxidation of wine } \\
\text { components }\end{array}$} & $0,113 \rightarrow 0,083$ \\
\hline Oxidation reduction potential, $\mathrm{mV}$ & & $250 \rightarrow 220$ \\
\hline Mass concentration of phenolic substances, $\mathrm{mg} / \mathrm{l}$ & & $263 \rightarrow 218$ \\
\hline
\end{tabular}




\section{Conclusion}

Thus, as a result of the studies carried out, it has been shown that the process of biological aging of wines under a sherry film causes a change in the component composition of the wine and its physicochemical characteristics:

- reduction of the volume fraction of ethyl alcohol, the mass concentration of the components of the acid complex (malic, lactic and acetic acids), amine nitrogen and glycerol as sources of energy and carbon nutrition for yeast;

- decrease in the content of phenolic substances, the value of the oxidation reduction potential of wine and optical density $\mathrm{D}_{420}$;

- increase in the mass concentration of aromatic substances formed during the oxidative metabolism of yeast: acetaldehyde, diacetyl, acetoin, dioxanes, dioxolans, lactones.

Based on the data obtained, the role of the main components of wines in the process of biological aging was established, and the ranges of their variation were determined. The important role of acetaldehyde and products of its interaction with wine components in the formation of specific organoleptic properties of Sherry is shown.

\section{References}

1. V. Gherzhikova, S. Cherviak. Viticulture and winemaking, 45, 92 (2015) (in Russian)

2. M. Cortés, J. Moreno, L. Zea, L. Moyano, M. Medina. J. Agric. Food Chem. 46, 2389 (1998)

3. R. Baron, M. Mayen, J. Merida, M. Medina. J. Agric. Food Chem. 45, 1682 (1997)

4. L. Zea, M. Serratosa, J. Mérida, L. Moyano. Comprehensive Reviews in Food Science and Food Safety, 14, 681 (2015)

5. L. Zea, L. Moyano, J. Moreno, B. Cortes, M. Medina. Food chemistry, 75, 79 (2001)

6. J. Mauricio, E. Valero, C. Millán, J. Ortega. J. Agric. Food Chem. 49, 3310 (2001)

7. B. Turcotte, X. Liang, F. Robert, N. Soontorngun. FEMS Yeast Res, 10, 2 (2010)

8. H.-J. Schuller. Current Genetics, 43, 139 (2003)

9. J. Bakker, R. Clarke. Wine Flavour Chemistry (Blackwell Publishing Ltd., 2012).

10. J.-L. Legras, J. Moreno-Garcia, S. Zara, G. Zara, T. Garcia-Martinez, J. Mauricio, I. Mannazzu, A. Coi, M. Zeidan, S. Dequin, J. Moreno, M. Budroni, Frontiers in Microbiology, 7, 503 (2016)

11. M. Moreno-Arribas, M. Polo, Wine chemistry and biochemistry (Springer Science+Business Media, LLC, 2009)

12. G. Cordero-Bueso, M. Ruiz-Muñoz, M. González-Moreno, S. Chirino, M. BernalGrande, J. Cantoral, Fermentation, 4 (2018)

13. A. Lea, J. Piggott, Fermented beverage production (Springer Science+Business Media New York, 2003)

14. E. Guichard, P. Etiévant, R. Henry, A. Mosandl. Z Lebensm Unters Forsch, 195, 540 (1992)

15. V. Gherzhikova, S. Cherviak, E. Ivanova, N. Gnilomedova, M. Ermihina, Magarach. Viticulture and winemaking, 2, 26 (2015)

16. V. Gherzhikova, Technochemical and microbiological control methods in winemaking (Simferopol: Tavrida, 2002) 
17. Compendium of international methods of wine and must analysis. Method OIV-MAAS2-07B. Chromatic Characteristics. Compendium of International Metods of Wine and Must Analysis (2016) 